\title{
Over Time Public E-Procurement Impacts: The Portuguese Case
}

\author{
Amílcar Arantes ${ }^{1}$ \& António Aguiar Costa ${ }^{2}$ \\ ${ }^{1}$ CESUR, Instituto Superior Técnico, Universidade de Lisboa, Portugal \\ ${ }^{2}$ ICIST, Instituto Superior Técnico, Universidade de Lisboa, Lisboa, Portugal \\ Correspondence: Amílcar Arantes, CESUR, Instituto Superior Técnico, Universidade de Lisboa, Portugal. \\ E-mail: amilcar.arantes@tecnico.ulisboa.pt
}

Received: March 17, 2014

Accepted: May 27, 2014

Online Published: June 25, 2014

doi:10.5539/ibr.v7n7p119

URL: http://dx.doi.org/10.5539/ibr.v7n7p119

\begin{abstract}
This research study appraises over time impacts of public e-procurement implementation in Portugal. To attain this objective, two surveys were conducted with public contracting authorities and economic operators, in 2010 and 2012 respectively. The main contribution of this exploratory research study was to demonstrate the distinct over time perspective of public contracting authorities and economic operators and evidence that economic operators are the most vulnerable to electronic market dynamics. The research study conducted shows that the vulnerability of the economic operators results from their susceptibility to excessive price-based competition and from the additional e-procurement costs introduced by e- procurement service providers. However, in general, it is relevant to highlight that public e-procurement have a global positive impact on public contracting authorities and economic operators and in both cases it resulted in a perception of increased transparency in the purchasing procedures of public entities.
\end{abstract}

Keywords: public procurement, e-procurement, public e-procurement, survey

\section{Introduction}

In terms of meliorating communication, cooperation and process efficiency and increasing approaches to projects and processes based on performance (Commission, 2010a, 2010c), Information and Communication Technologies (ICT) have a strategic role and its advantages are widely recognized. For instance, in Europe, the use of ICT has shown steady progress regarding the availability of online services (Commission, 2009) and the use of ICT in public procurement processes is a matter of the highest importance, with public e- procurement being considered an significant contribution on the way to an efficient, less bureaucratic and transparent society that has good influences on relationships between buyers and suppliers (Ellram \& Zsidisin, 2002; Johnson, 2011; Narasimhan \& Das, 2001).

Grounded on these advantages and with the objective of building a single European market for e-procurement, the Manchester Declaration (2005), stated that by 2010 all public administrations through Europe would have the capability of running $100 \%$ of their procurement electronically and at least $50 \%$ of public procurement above the EU public procurement threshold would be carried out electronically. However, in 2010 the Member States of the EU were still away from those availability goals stated in the Manchester Declaration (Commission, 2010a). The exception to this low rate of use of public e-procurement is Portugal (Commission, 2010b), where public procurement has been fully electronic since November 2009, which makes the country the first capable of evaluate the impacts of public e-procurement in both public Contracting Authorities (CAs) and Economic Operators (EOs). Currently, e-submission is widespread and even obligatory in several European countries.

There are several works published on public e-procurement implementation and impact assessment (Costa, Arantes, \& Valadares Tavares, 2013; S. Croom \& A. Brandon-Jones, 2007; Croom \& Brandon-Jones, 2005; Johnson, 2011; McConnell, Doherty, \& Ellis-chadwick, 2010; Vaidya, Sajeev, \& Callendar, 2006). Nevertheless, works assessing the dynamics of public e-procurement over time and the change in perceptions as to the impacts of e-procurement are unknown. The aim of this research is to expand the existing literature in the field of public e-procurement, in particular regarding to the public e-procurement impacts on CAs and EOs and their over time dynamics. Therefore, two national surveys were conducted focusing on the impacts of public e-procurement, including both CAs and EOs. The first survey was conducted in 2010, one year after e-procurement became fully obligatory, and the second survey in 2012. 


\section{Public E-Procurement}

\subsection{Impacts of Public E-Procurement}

Public procurement accounts for more than 17\% of GDP in the EU (Commission, 2010d), thus substantial improvements can be attained by raising procurement efficiency. The potential gains in efficiency are even enhanced because the majority of public contracts are extremely complex, costly, have low transparency. Furthermore, public contracts are known as being bureaucratic and rigid processes, demanding regular renegotiation and management of conflicts (Spiller, 2008; Tavares, 2008). So, e-procurement arises in the public sector with the purpose of decreasing complexity and ameliorating transparency and competitiveness (S. Croom \& A. Brandon-Jones, 2007; Croom \& Brandon-Jones, 2005; Duyshart, Mohamed, Hampson, \& Walker, 2003; Johnson, 2011).

Puschmann and Alt (2005) confirmed with their benchmark study that e-procurement can effectively contribute to efficiency and effectiveness gains. Throughout their study, these authors evidenced the following e-procurement benefits: reduction or elimination of authorization steps; limited regulation of exceptions at the beginning; paper elimination; suppliers' integration in the process; and accounting of the whole procurement process, from looking for articles to invoicing. These benefits result from the elimination of the difficulties encountered in traditional procurement, stimulating more forthright and integrated approaches focused on a wider variety of procurement subjects. So, with e-procurement, the contract becomes the centerpiece of the process taking into consideration more strategic perspectives of procurement, which could not be considered in traditional approaches (Collins, 1999; Vincent-Jones, 2006). In this electronic context, the contracts are more rigorous and easier to execute, once the pertinent information is reachable via the electronic platform, and more care can be focused to matters that are non-operational (Vaidya et al., 2006).

According to the existing data, a reduction of $3 \%$ of public expenditure maintaining the output can be achievable through the public e-procurement (Commission, 2010b; Duyshart et al., 2003), with gains in transparency, accountability and integrity in the public procurement process (Armstrong, 2005). In the literature it is possible to find several studies that emphasize the relevance of public e-procurement and reveals its advantages (S. Croom \& A. Brandon-Jones, 2007; Croom \& Brandon-Jones, 2005; McConnell et al., 2010; Vaidya et al., 2006). Croom and Brandon-Jones (2005) found out that the major issues related with the e-procurement implementation are the following: impact on cost efficiency; impact on the kind and form of the transaction with suppliers; the implementation of e-procurement system, wider issues in the IT infrastructure; and the influence of e-procurement in the social relationships between actors of the procurement process. These authors evidenced that the economic benefits were the main driver for e-procurement implementation. They also stressed the high relevance of the commitment and support of the organization and emphasized training as a central issue inducing the approval of the purchasing tools supported on the internet. These findings resulted from a research on e-procurement application in a set of organizations of the UK public sector. Later, also Croom \& Brandon-Jones (2007), considering a set of nine organizations from the public sector found that the e-procurement outcome is largely applicable and that many of the benefits announced in the literature can indeed be achieved. This study was focused on the specification of the purchasing system, the management of the implementation, the changes in total costs of the acquisitions and, finally, the changes of the organization characteristics and governance structures. Once again, the impact of e-procurement on costs was found.

Taking in consideration that e-procurement platforms are probable to promote changes in markets, and that these changes should be taken into account in the discussion, it is necessary to investigate the impacts of e-procurement. In fact, e-procurement instruments decrease costs related with search and coordination of the players, giving detailed product price and information, which promotes increased transparency and boost markets, in particular price-based markets like commodity markets, towards the idea of a market where buyers are, at no cost, completely informed about seller prices (Bakos, 1997).

Some authors (Bakos, 1997; Riggins, Kriebel, \& Mukhopadhyay, 1994; Wang \& Seidmann, 1995) believed that this scenario may conduct to a growth on the number of suppliers present in procurement procedures and may drive suppliers to a competitive price-taking equilibrium, improving buyers' benefits and reducing sellers' power. As a consequence, quality reduction in supply (delays, interruptions, fewer customer support, etc.) may happen motivated by the strong price competition. For example, as Mithas et al. (2002) claim that buyers face a huge quandary when changing from their current supply chain relationships to e-markets, as the change can damage existing social networks and spoil future purchasing. Hence, although at first look the use of e-procurement appears to encourage limitless expansion of e-markets, a more complete analysis may display that in complex and diversified markets the intense competition stimulated by electronic instruments can promote desertion by 
users (Costa \& Tavares, 2013, 2014). Furthermore, a more deep comprehension of e-procurement may reveal that suppliers are the more weak party in a dematerialized procurement process and, consequently, may necessitate particular attention.

\subsection{The Portuguese Case}

In the Portuguese case, the Public Contract Code, Decree-Law 18/2008, transposed the pertinent European Union directives to the legal system of Portugal (Commission, 2004). The law had various objectives (Mateus, Ferreira, \& Carreira, 2010), for instance full implementation of e-procurement; wide flexibility of procedures to prize contracts, including new possibilities, such as reverse auctions, dynamic acquisitions systems and framework agreements; and availability to any bidder of the complete description of the multi-criteria model for assessing tenders before having to present its tender. Underneath the Public Contract Code all actors are required to communicate and interact over the Internet, use qualified e-procurement platforms and validate processes through digital signatures. These requests presented important alterations to the cooperation and working processes between CAs and EOs. Nevertheless, between July $30^{\text {th }} 2008$ (the implementation of the Decree-Law 18/2008) and November $1^{\text {st }} 2009$ (the obligatory use of e-procurement) both electronic-based and paper-based procurement could be utilized.

The e-procurement implementation in Portugal followed a decentralized model, in contrast to several countries across Europe where e-procurement implementation relies on the mandatory use of a single platform (Assar \& Boughzala, 2008; Commission, 2009). In the decentralized implementation model, the e-procurement platform market is more competitive but still regulated and, therefore, each platform must fulfil with rigid safety and security requests (Betts et al., 2006; Polemi \& Papastergiou, 2006). So, it is predictable that, in the Portuguese case, the presence of eight platforms raises competition and encourages the outgrowth of more proficient solutions, integrating business processes, promoting green procurement, increasing cooperation and e-supply chain management. In the decentralized Portuguese e-procurement platform market, the CAs may select the most appropriate platform from the existent set of platforms qualified by a Supervisory Board providing general services and, if request, differentiated services (InCI, 2012), while the EOs may have access to all platforms(they just need to ask for registration in each one).

Taking into account the impacts of public e-procurement (namely transparency, process cost, process bureaucracy, process duration, market competition, and value for money) and their over time dynamics, the following two research questions can be formulated: are the perceptions of public e-procurement impacts different between CAs and EOs? And do these perceptions change over time? By answering these questions, this research contributes to increasing the knowledge on public e-procurement and stressing the dynamics of its impact perception in CAs and EOs.

The paper begins with a literature review concerning public e-procurement implementation impacts and the Portuguese case. Subsequently, the research methodology is described, followed by the presentation and discussion of the obtained results. Finally, conclusions and findings are presented and main implications discussed.

\section{Research Methodology}

Aiming to assess the perceptions on the impacts of implementation of public e-procurement in Portugal and their over time dynamics, both in CAs and in EOs, two surveys were carried out. The first survey was carried out in 2010, one year after obligatory e-procurement (forced by the new Public Contract Code) and the second survey two years later. Therefore, these two surveys, carried out at different phases of the e-procurement implementation process, permit for a wider comprehension of the Portuguese case and impacts of public e-procurement.

In both surveys data collection were cross-sectional and supported by electronic instruments. In terms of questionnaire design, care was taken to achieve consistent meaning for all respondents, to avoid ambiguity and unsuitable wording to increase the quality of responses (Fowler, 2009). Furthermore, the questionnaire was prepared supported on guidelines from existing research works (S. Croom \& A. Brandon-Jones, 2007; Vaidya et al., 2006). Also, with the purpose of validation of the questionnaire based essentially in the literature review, a set of meetings were conducted with CAs and EOs. These meetings involved experienced management personnel in e-procurement.

As a result, a set of questions (Table 1) was settled in accordance with the research questions previously developed, therefore maintaining methodological consistency (Saunders, Lewis, \& Thornhill, 2009). Also, the number of questions was kept to a minimum to allow achieving higher response rate, while still guaranteeing the 
gathering of the required data.

Table 1. Survey questions

\begin{tabular}{l}
\hline Survey questions - Does e-procurement have an impact on: \\
1. Procurement process costs? \\
2. Procurement process length? \\
3. Supply market competition? \\
4. Procurement process transparency? \\
5. Procurement process bureaucracy? \\
6. Average value?
\end{tabular}

The questions designed to assess the respondents' perception of the impacts of public e-procurement used a three-point Likert scale ( 1 = Negative impact, 2 = No impact; and 3 = Positive impact $)$, as the interviews previous to the design of the questionnaire shown the respondents' reluctance in describing in more detail their perceptions using more than three response levels. Besides, the authors are of the opinion that a three-point Likert scale is suitable for the exploratory nature of the study in accordance with Jacoby \& Mattel (1971).

In order to validate the questionnaire, the authors' colleagues, researching in the areas of supply chain management and procurement, tested the first version of the questionnaire and the cover message. Afterwards, additional tests were performed in a restricted and controlled set of CAs and EOs. This procedure allowed improving and adjusting the questionnaire, guaranteeing its effectiveness in gathering information and removing misinterpretations or uncertainties.

The questionnaire was sent to a list of CAs and EOs belonging to a set of organizations supplied by the InCI (Institute for Construction and Real State). InCI is a public institute that is in charge for the supervision of the Public Contracts Portal, aggregating all information on public contracts. As stated in the Public Contract Code, all contracts and involved entities are obliged to be registered in the Public Contracts Portal, managed by InCI, which allows assuming that the list of entities used in the surveys are representative of the universe of entities using e-procurement.

Finally the statistical package (SPSS) was used to perform the statistical analyses, which comprised testing the null hypothesis that the mean values of the perceived impacts of public e-procurement are identical, when comparing them by year and type of entity. The procedure adopted was the following:

- $\quad$ it was assumed that the dependent variables (the perceived impacts) were normally distributed;

- to verify if the variances in the dependent variables were statistically equivalent it was used the Levene $\mathrm{F}$ test of homogeneity;

- $\quad$ if the variances of the dependent variables were statistically equivalent, then a T-student test assuming equal variance was used;

- $\quad$ if the dependent variables had variances statistically different, then a T-student test not assuming equal variance was undertaken;

- additionally, to test the "No impact" value of the overall means the T-student test was utilized;

- in all the statistical tests, the statistical significance is obtained when the p-values are less than $\alpha=0.05$ (Forza, 2002).

This procedure permitted to verify whether or not the perceptions of CAs and EOs were identical on the different topics researched in this study, and if their perceptions changed over time.

\section{Results}

In essence, the research intents to analyze the perception CAs and EOs on the impacts of public e-procurement implementation, assessing and comparing them in terms of mean values. As the surveys were conducted for each type of entity for 2010 and 2012, it is possible to confront the results by year and by entity.

\subsection{General Data}

The questionnaire was sent to 2900 CAs and 2000 EOs by e-mail, both 2010 and 2012. With the objective of achieving a high number of responses, the questionnaire survey and the cover text were sent three times in a time 
period of six weeks. The number of respondents is shown in Table 2 according to the survey year and type of entity. Once the respondents number is always above 44 (Forza, 2002), it can be considered that there are sufficient responses to guarantee statistical inferences with a statistical significance level $(\alpha)$ of 0.05 and power $(\beta)$ of 0.8 .

Table 2. Survey respondent characterization

\begin{tabular}{lccrrr}
\hline & Potential respondents 2010/12 & \multicolumn{2}{c}{ Respondents 2010 } & \multicolumn{2}{c}{ Respondents 2012 } \\
\hline Public contracting authorities & 2900 & 201 & $6.9 \%$ & 125 & $4.3 \%$ \\
Private contractors & 2000 & 70 & $3.5 \%$ & 66 & $3.3 \%$ \\
\hline
\end{tabular}

As it is possible to verify, the survey response rates were low (Table 2), which is frequent in surveys using e-mail (Sax, Gilmartin, \& Bryant, 2003). In this specific case, this behavior may have been potentiated by the fact that these surveys are being conducted every year since 2009, thus reducing the willing of potential respondents to cooperate over time. As a result of the reduced response rate, the nonresponse bias could become an issue (Kypri, Stephenson, \& Langley, 2004). However, in the present case, this issue may be of small importance once, since the sample distribution by entities 'type is identical to its distribution in the real population (Costa et al., 2013).

\subsection{Impacts}

Considering the impacts of public e-procurement implementation, the analysis focused on the hypotheses considered in the research, which centered on the different perceptions of CAs and EOs in a determined year and over time. Consequently, in the following particular attention will be paid to the results obtained in the surveys of 2010 and 2012 and the respective comparison will be analyzed discussed.

In 2010, looking at the impact perceptions on public e-procurement of the CAs (Table 3), one must emphasize that only for "Market competition", "Procurement process transparency" and "Average value" has the impact of e-procurement been sensed, and it has been positive in all cases. Considering now the impact perceptions of the EOs', it can be said that public e-procurement had a broader impact hence all impact perceptions where positive with the exception of "Procurement process length" that presented a statistical significant score of 2 (which means no impact was perceived).

Using the T-student test to compare both types of entities, it can be seen that the CAs and EOs had a different perception in terms of "Procurement process costs", "Procurement process bureaucracy" and "Market competition" and in all cases EOs presented more positive perceptions. These results are not strange to the fact that EOs are more willing to recognize the advantages of a paperless procurement process, which may conduct to substantial cost and bureaucracy savings and, if combined with online information access on public procurement tenders, increased market competition.

In general, we can conclude that public e-procurement implementation had a positive impact on both CAs and EOs, and that the positive impact perceptions were stronger in the case of the EOs. It is interesting to stress that in both entities the most positive impact perception happened for "Procurement process transparency", which is aligned with the results found in the literature (Croom \& Brandon-Jones, 2005; S. R. Croom \& A. Brandon-Jones, 2007; Johnson, 2011; Vaidya et al., 2006).

Table 3. Impacts comparison between CAs and EOs, 2010

\begin{tabular}{|c|c|c|c|c|c|c|}
\hline \multirow{2}{*}{ Impacts } & \multicolumn{3}{|c|}{ Average* } & \multirow[t]{2}{*}{ T-student Sig.** } & \multicolumn{2}{|c|}{ T-student Sig.*** } \\
\hline & CAs & EOs & Overall & & CAs & EOs \\
\hline Procurement process costs & 2.08 & 2.40 & 2.16 & $0.004 * \mathrm{~V}$ & 0.158 & 0.000 \\
\hline Procurement process length & 2.09 & 2.08 & 2.09 & 0.920 & 0.173 & 0.488 \\
\hline Market competition & 2.14 & 2.44 & 2.22 & 0.006 & 0.013 & 0.000 \\
\hline Procurement process transparency & 2.64 & 2.52 & 2.61 & $0.214 * \mathrm{~V}$ & 0.000 & 0.000 \\
\hline Procurement process bureaucracy & 1.94 & 2.42 & 2.06 & $0.000 * \mathrm{~V}$ & 0.347 & 0.000 \\
\hline Average value & 2.25 & 2.26 & 2.25 & 0.921 & 0.000 & 0.005 \\
\hline
\end{tabular}

*Values represented on a three-point Likert scale (a score greater than 2 denotes a positive impact);

**Statistical significance of the comparison between CAs and EOs means;

$* * *$ Statistical significance of the comparison between the means and the test value $=2$;

${ }^{*} \mathrm{~V}$ Equal variance not assumed. 
The 2012 CAs' opinion revealed that the same positive impact perceptions of e-procurement implementation as in 2010, namely "Market competition", "Procurement process transparency" and "Average value", plus "Procurement process costs" (Table 4). On the other hand, EOs have perceived positive impacts in "Market competition", "Procurement process transparency", "Procurement process bureaucracy" and "Average value", and no impact in terms of "Procurement process costs" and "Procurement process length". Comparing with 2010, the perceived impact in "Procurement process costs" decreased from positive to no impact in 2012.

Finally, CAs and EOs had a different impact perception in terms of "Procurement process costs" and "Procurement process bureaucracy", with a greater impact perception by CAs in the former and by EOs in the latter. The fact that the CAs have a greater level of impact perception concerning "Procurement process costs" is mostly because CAs e-procurement process is more complex so the potential gains are also higher. So, if in 2010 CAs were more pessimistic, due to the higher learning curve inherent to their more complex processes, in 2012 this situation inverted. On the contrary, the EOs lower level of impact perception in "Procurement process costs" is related to recent rises in the cost of time stamps imposed by e-procurement service providers and the surge in competition. Concerning "Procurement process bureaucracy", the main reason why EOS have greater impact perception is the fact that with e-procurement they the entire process is paperless.

In general, public e-procurement implementation had a positive impact perception on CAs and EOs and, in both, the impact on "Procurement process transparency" was the most positive, as in 2010 was already the case.

Table 4. Impacts comparison between CAs and EOs, 2012

\begin{tabular}{|c|c|c|c|c|c|c|}
\hline \multirow{2}{*}{ Impacts } & \multicolumn{3}{|c|}{ Average* } & \multirow[t]{2}{*}{ T-student Sig.** } & \multicolumn{2}{|c|}{ T-student Sig.**** } \\
\hline & CAs & EOs & Overall & & CAs & EOs \\
\hline Procurement process costs & 2.18 & 1.85 & 2.06 & 0.004 & 0.009 & 0.105 \\
\hline Procurement process length & 2.08 & 2.17 & 2.11 & 0.462 & 0.288 & 0.064 \\
\hline Market competition & 2.36 & 2.39 & 2.37 & 0.789 & 0.000 & 0.000 \\
\hline Procurement process transparency & 2.58 & 2.45 & 2.53 & $0.162 * \mathrm{~V}$ & 0.000 & 0.000 \\
\hline Procurement process bureaucracy & 1.98 & 2.24 & 2.08 & 0.046 & 0.841 & 0.014 \\
\hline Average value & 2.29 & 2.28 & 2.28 & 0.954 & 0.000 & 0.001 \\
\hline
\end{tabular}

*Values represented on a three-point Likert scale (a score greater than 2 denotes a positive impact);

**Statistical significance of the comparison between CAs and EOs means;

$* * *$ Statistical significance of the comparison between the means and the test value $=2$;

${ }^{*} \mathrm{~V}$ Equal variance not assumed.

Considering the evolution of the impact perceptions of the of public e-procurement implementation by each type of respondent entity over time, it is possible to verify that for CAs there was a significant variation only in terms of the perception about "Market competition", which has improved positively (Table 5). For the EOs, the only change found was in terms of "Procurement process costs", which decreased (Table 6). Consequently, globally a distinct behavior can be perceived in CAs and EOs. While the impact perceptions by CAs have been enhanced, the perception by EOs has dropped.

Nevertheless, examining the results in terms of the average global impacts (calculated as the average of all impacts by type of entity for each year, Table 7), it is possible to verify that the perceptions of CAs, with statistical significance, remained constant from 2010 to 2012. On the contrary, the global perception of public e-procurement impacts by EOs has diminished over time and converged towards the average global impact as perceived by CAs. 
Table 5. Over time impacts of public e-procurement - CAs

\begin{tabular}{|c|c|c|c|c|}
\hline \multirow{2}{*}{ CAs - Impacts } & \multicolumn{3}{|c|}{ Average* } & \multirow{2}{*}{ T-student Sig.** } \\
\hline & 2010 & 2012 & Overall & \\
\hline Procurement process costs & 2.08 & 2.18 & 2.12 & 0.220 \\
\hline Procurement process length & 2.09 & 2.08 & 2.09 & $0.932 * * *$ \\
\hline Market competition & 2.14 & 2.36 & 2.23 & 0.011 \\
\hline Procurement process transparency & 2.64 & 2.58 & 2.62 & 0.306 \\
\hline Procurement process bureaucracy & 1.94 & 1.98 & 1.96 & 0.655 \\
\hline Average value & 2.25 & 2.29 & 2.26 & 0.591 \\
\hline
\end{tabular}

*Values represented on a three-point Likert scale (a score greater than 2 denotes a positive impact);

**Statistical significance of the comparison between mean perceptions in 2010 and 2012;

$* * *$ Equal variance not assumed.

Table 6. Over time impacts of public e-procurement - EOs

\begin{tabular}{|c|c|c|c|c|}
\hline \multirow{2}{*}{ EOs - Impacts } & \multicolumn{3}{|c|}{ Average* } & \multirow{2}{*}{ T-student Sig.** } \\
\hline & 2010 & 2012 & Overall & \\
\hline Procurement process costs & 2.40 & 1.85 & 2.12 & 0.000 \\
\hline Procurement process length & 2.08 & 2.17 & 2.13 & $0.510 * *$ \\
\hline Market competition & 2.44 & 2.39 & 2.42 & 0.649 \\
\hline Procurement process transparency & 2.52 & 2.45 & 2.48 & 0.511 \\
\hline Procurement process bureaucracy & 2.42 & 2.24 & 2.33 & 0.208 \\
\hline Average value & 2.26 & 2.28 & 2.27 & 0.848 \\
\hline
\end{tabular}

*Values represented on a three-point Likert scale (a score greater than 2 denotes a positive impact);

**Statistical significance of the comparison between mean perceptions in 2010 and 2012;

***Equal variance not assumed.

Table 7. Average global impact by type of entity and by year

\begin{tabular}{lccc}
\hline & \multicolumn{2}{c}{ Mean* } & T-student Sig.** \\
\cline { 2 - 3 } & 2010 & 2012 & 0.323 \\
\hline CAs & 2.19 & 2.24 & 0.049 \\
\hline EOs & 2.36 & 2.23 & \\
\hline
\end{tabular}

* Values represented on a three-point Likert scale (a score greater than 2 denotes a positive impact);

**Statistical significance of the comparison between mean perceptions in 2010 and 2012;

***Statistical significance of the comparison between mean perceptions CAs and Eos.

\section{Conclusions}

Important changes have been implemented in the public sector during last years, predominantly in terms of the dematerialization of processes. In fact, today e-instruments are extensively used to support and ameliorate various government services. Amongst current government e-solutions, e-procurement is likely the most pertinent, mainly because of its major impacts on public expenditure and in the efficiency of the process.

Portugal was the first case in the European Union where the use of e-procurement turned obligatory for all types of procurement processes. Therefore, it presents itself as an interesting and relevant case to undertake an exploratory research focusing the impacts of public e-procurement. With this aim, surveys were conducted in 
two distinct years, enabling the understanding the main impacts of e-procurement on CAs and EOs.

The survey results allowed answering the two research questions formulated at the beginning of this research and made possible the following findings:

- The EOs had a more positive perception on e-procurement impacts in the first year of public e-procurement adaptation;

- Over time this difference was nullified as a consequence of the reduction in the perceived impacts of e-procurement by EOs;

- As a consequence of the previous points, the perceptions of CAs and EOs became identical over time;

- The average global results were positive for CAs and EOs in both years, although the perception has changed negatively for EOs.

From the findings, it can be pointed out that EOs are the most susceptible to e-market changes over time, once e-markets growing competition may result in excessive price-based competition, which may be damaging for EOs. Also, there was a reduction in the perception of impacts for EOs, largely due to a less positive perception in terms of procurement process costs. This alteration, which may be originated by a recent rise in the cost of time stamps imposed by e-procurement service providers and the surge in competition, led to a reduction on the supplier margins per tender submitted. Thus, the higher costs associated to e-procurement for EOs caused a less positive impact perception of public e-procurement, indicating that EOs are the most vulnerable to changes imposed by public e-procurement service providers.

Concluding, it is important to refer that public e-procurement may in fact increase competition, decrease processes complexity and induce considerable savings, which is consistent with the literature. Although the overall opinion of CAs and EOs is positive, it became clear throughout the study that it is crucial to understand the overtime dynamics of CAs and EOs in order to leverage the positive impacts of public e-procurement. The present research effectively improved the understanding about e-procurement and emphasized that CAs and EOs have completely different roles in the process, which must be faced distinctly.

Based on the findings, it is relevant to emphasize the following implication: to realize the full potential of public e-procurement, there must be a proactive and effective regulation of public e-procurement, which should consider the dynamics of e-markets and the vulnerability of EOs.

As further developments, it would be of great interest to conduct more specific surveys, in partnership with e-procurement service providers, in order to monitor CAs and EOs dynamics over time, support service providers' decisions and improve their management capabilities.

The type of survey chosen is the principal limitation of this study. The low response rates achieved are common among web-supported, distributed by e-mail. Moreover no incentives were given and no follow up mechanism has been implemented. Nevertheless, in terms of characteristics like the administrative level, in the case of CAs, and size, in the case of EOs, the surveys answers were distributed in accordance to the population distribution, which could reveal that, to some degree, the nonresponse bias is small.

\section{Acknowledgments}

The authors are grateful to the Portuguese Technology and Engineering Observatory (OPET) and to the Portuguese Public Markets Association (APMEP) for their support in conducting the surveys.

\section{References}

Armstrong, E. (2005). Integrity, Transparency and Accountability in Public Administration: Recent Trends. Regional and International Developments and Emerging Issues, United Nations.

Assar, S., \& Boughzala, I. (2008). Empirical evaluation of public e-procurement platforms in France. International Journal of Value Chain Management, 2(1), 30-42. http://dx.doi.org/10.1504/IJVCM.2008.016120

Bakos, J. Y. (1997). Reducing Buyer Search Costs: Implications for Electronic Marketplaces. Management Science, 43(12), 1676-1692. http://dx.doi.org/10.1287/mnsc.43.12.1676

Betts, M., Black, P., Christensen, S., Dawson, E., Du, R., Duncan, W., \& González, J. (2006). Towards secure and legal e-tendering. Journal of Information Technology in Construction, 11, 89-102.

Collins, H. (1999). Regulating Contracts. New York: Oxford University Press.

Commission, E. (2004). A report on the functioning of public procurement markets in the EU: benefits from the 
application of EU directives and challenges for the future. Retrieved from http://ec.europa.eu/internal_market/publicprocurement/docs/public-proc-market-final-report_en.pdf

Commission, E. (2009). Smarter, Faster, Better eGovernment, 8th Benchmark Measurement. Retrieved from http://ec.europa.eu/information_society/eeurope/i2010/docs/benchmarking/egov_benchmark_2009.pdf

Commission, E. (2010a). Europe's Digital Competitiveness Report 2010. Retrieved from http://ec.europa.eu/information_society/digital-agenda/documents/edcr.pdf

Commission, E. (2010b). Green Paper on expanding the use of e-procurement in the EU. Brussels: European Commission.

Commission, E. (2010c). ICT and e-Business for an Innovative and Sustainable Economy. 7th Synthesis Report of the Sectoral e-Business Watch, Brussels.

Commission, E. (2010d). Public Procurement Indicators 2008. Brussels, Belgium. Retrieved from http://ec.europa.eu/internal_market/publicprocurement/docs/indicators2008_en.pdf

Costa, A. A., Arantes, A., \& Valadares Tavares, L. (2013). Evidence of the impacts of public e-procurement: The Portuguese experience. Journal of Purchasing and Supply Management, 19(4), 238-246. http://dx.doi.org/10.1016/j.pursup.2013.07.004

Costa, A. A., \& Tavares, L. V. (2013). Advanced multicriteria models to promote quality and reputation in public construction e-marketplaces. Automation in Construction, 30(0), 205-215. http://dx.doi.org/10.1016/j.autcon.2012.11.029

Costa, A. A., \& Tavares, L. V. (2014). Social e-business as support for construction e-procurement: e-procurement network dynamics. Automation in Construction, 43(0), 180-186. http://dx.doi.org/10.1016/j.autcon.2014.03.019

Croom, S. R., \& Brandon-Jones, A. (2005). Key Issues in E-procurement: Procurement Implementation and Operation in the Public Sector. Journal of Public Procurement, 5(3), 367-387.

Croom, S. R., \& Brandon-Jones, A. (2007). Impact of e-procurement: Experiences from implementation in the UK public sector. Journal of Purchasing and Supply Management, 13(4), 294-303. http://dx.doi.org/10.1016/j.pursup.2007.09.015

Declaration, M. (2005). Ministerial Declaration approved unanimously on 24 November 2005. Manchester.

Duyshart, B., Mohamed, S., Hampson, K. D., \& Walker, D. H. T. (2003). Enabling Improved Business Relationships - How Information Technology Makes a Difference. In D. Walker \& K. Hampson (Eds.), Procurement Strategies: A Relationship-based Approach (pp. 123-166). UK: Blackwell Publishing.

Ellram, L. M., \& Zsidisin, G. A. (2002). Factors that drive purchasing and supply management's use of information technology. Engineering Management, IEEE Transactions on, 49(3), 269-281. http://dx.doi.org/10.1109/TEM.2002.803381

Forza, C. (2002). Survey research in operations management: a process-based perspective. International Journal of Operations \& Production Management, 22(2), 152-194. http://dx.doi.org/10.1108/01443570210414310

Fowler, F. J. (2009). Survey Research Methods. California: Sage Publications.

Jacoby, J., \& Mattel, M. (1971). Three-Point Likert Scales Are Good Enough. Journal of Marketing Research (JMR), 8(4), 495-500. http://dx.doi.org/10.2307/3150242

Johnson, M. (2011). Public sector e-procurement: a study of benefits from e-markets in the local government sector. International Journal of Services Technology and Management, 16(1), 1-27. http://dx.doi.org/10.1504/IJSTM.2011.041975

Kypri, K., Stephenson, S., \& Langley, J. (2004). Assessment of Nonresponse Bias in an Internet Survey of Alcohol Use. Alcoholism: Clinical and Experimental Research, 28(4), 630-634. http://dx.doi.org/10.1097/01.ALC.0000121654.99277.26

Mateus, R., Ferreira, J. A., \& Carreira, J. (2010). Full disclosure of tender evaluation models: Background and application in Portuguese public procurement. Journal of Purchasing and Supply Management, 16(3), 206215. http://dx.doi.org/10.1016/j.pursup.2010.04.001

McConnell, D. J., Doherty, N. F., \& Ellis-chadwick, F. (2010, 19-21 May 2010). Exploring the uptake and application of electronic procurement to central and local government. Paper presented at the Research Challenges in Information Science (RCIS), 2010 Fourth International Conference on. 
Mithas, S., Jones, J., \& Mitchell, W. (2002). Non-contractible Factors as Determinants of Electronic Market Adoption. Paper presented at the International Conference on Information Systems, Barcelona.

Narasimhan, R., \& Das, A. (2001). The impact of purchasing integration and practices on manufacturing $\begin{array}{llll}\text { performance. Journal of } \text { Operations } & \text { Management, 19(5), }\end{array}$ http://dx.doi.org/10.1016/S0272-6963(01)00055-9

Polemi, D., \& Papastergiou, S. (2006). A Secure e-Ordering Web Service. Project E-Society: Building Bricks (Vol. 226, pp. 352-365). Springer Boston.

Puschmann, T., \& Alt, R. (2005). Successful use of e-procurement in supply chains. Supply Chain Management: An International Journal, 10(2), 122-133. http://dx.doi.org/10.1108/13598540510589197

Riggins, F. J., Kriebel, C. H., \& Mukhopadhyay, T. (1994). The growth of interorganizational systems in the presence of network externalities. Manage. Sci., 40(8), 984-998. http://dx.doi.org/10.1287/mnsc.40.8.984

Saunders, M., Lewis, P., \& Thornhill, A. (2009). Research methods for business students (5th ed.). UK: Financial Times/Prentice Hall.

Sax, L. J., Gilmartin, S. K., \& Bryant, A. N. (2003). Assessing Response Rates and Nonresponse Bias in Web and Paper Surveys. Research in Higher Education, 44(4), 409-432. http://dx.doi.org/10.1023/A:1024232915870

Spiller, P. T. (2008). An Institutional Theory of Public Contracts: Regulatory Implications. Working paper (N0.14152).

Tavares, L. V. (2008). A Gestão das Aquisições Públicas: Guia de Aplicação do Código dos Contratos Públicos - Decreto-Lei 18/2008 - Empreitadas, Bens e Serviços (Management of public purchasing: guidelines for the application of the new Public Procurement Code - Decree-Law 18/2008). Lisboa, Portugal: OPET Observatório de Prospectiva da Engenharia e da Tecnologia, Lisboa.

Vaidya, K., Sajeev, A. M., \& Callendar, G. (2006). Critical Factors that Influence E-Procurement Implementation Success in the Public Sector. Journal of Public Procurement, 6(1/2), 70-99.

Vincent-Jones, P. (2006). The New Public Contracting: Regulation, Responsiveness, Relationality. Oxford: Oxford University Press. http://dx.doi.org/10.1093/acprof:oso/9780199291274.001.0001

Wang, E. T. G., \& Seidmann, A. (1995). Electronic Data Interchange: Competitive Externalities and Strategic Implementation Policies. Management Science, 41(3), 401-418. http://dx.doi.org/10.1287/mnsc.41.3.401

\section{Copyrights}

Copyright for this article is retained by the author(s), with first publication rights granted to the journal.

This is an open-access article distributed under the terms and conditions of the Creative Commons Attribution license (http://creativecommons.org/licenses/by/3.0/). 